NBER WORKING PAPER SERIES

\title{
CAPITAL GAINS TAXES AND ASSET PRICES: CAPITALIZATION OR LOCK-IN?
}

\author{
Zhonglan Dai \\ Edward Maydew \\ Douglas A. Shackelford \\ Harold H. Zhang \\ Working Paper 12342 \\ http://www.nber.org/papers/w12342
}

\author{
NATIONAL BUREAU OF ECONOMIC RESEARCH \\ 1050 Massachusetts Avenue \\ Cambridge, MA 02138 \\ June 2006
}

We thank Ashiq Ali, Robert Kieschnick, Suresh Radhakrishnan, Scott Weisbenner, Yexiao Xu, the associate editor, an anonymous referee, and seminar participants at the 2006 NBER Behavioral Response to Taxation/Public Economics Program Meeting, the 2006 UNC Tax Symposium, and the University of Texas at Dallas for helpful comments. Zhonglan Dai is at the School of Management, University of Texas at Dallas, Richardson, TX 75083, zdai@utdallas.edu, Edward Maydew is at the Kenan-Flagler Business School, University of North Carolina, Chapel Hill, NC 27599, Edward_Maydew@unc.edu, Douglas A. Shackelford is at the Kenan-Flagler Business School, University of North Carolina, Chapel Hill, NC 27599, Douglas_Shackelford@kenan-flagler.unc.edu, Harold H. Zhang is at the School of Management, University of Texas at Dallas, Richardson, TX 75083, harold.zhang@utdallas.edu. All errors are our own. The views expressed herein are those of the author(s) and do not necessarily reflect the views of the National Bureau of Economic Research.

(C2006 by Zhonglan Dai, Edward Maydew, Douglas A. Shackelford and Harold H. Zhang. All rights reserved. Short sections of text, not to exceed two paragraphs, may be quoted without explicit permission provided that full credit, including $($ ) notice, is given to the source. 
Capital Gains Taxes and Asset Prices: Capitalization or Lock-In?

Zhonglan Dai, Edward Maydew, Douglas A. Shackelford and Harold H. Zhang

NBER Working Paper No. 12342

June 2006

JEL No. H2, G1, D4, M4

\begin{abstract}
This paper examines the impact on asset prices from a reduction in the long-term capital gains tax rate using an equilibrium approach that considers both demand and supply responses. We demonstrate that the equilibrium impact of capital gains taxes reflects both the capitalization effect (i.e., capital gains taxes decrease demand) and the lock-in effect (i.e., capital gains taxes decrease supply). Depending on time periods and stock characteristics, either effect may dominate. Using the Taxpayer Relief Act of 1997 as our event, we find evidence supporting a dominant capitalization effect in the week following news that sharply increased the probability of a reduction in the capital gains tax rate and a dominant lock-in effect in the week after the rate reduction became effective. Nondividend paying stocks (whose shareholders only face capital gains taxes) experience higher average returns during the week the capitalization effect dominates and stocks with large embedded capital gains and high tax sensitive investor ownership exhibit lower average returns during the week the lock-in effect dominates. We also find that the tax cut increases the trading volume during the week immediately before and after the tax cut becomes effective and in stocks with large embedded capital gains and high tax sensitive ownership during the dominant lock-in week.
\end{abstract}

\author{
Zhonglan Dai \\ School of Management \\ University of Texas at Dallas \\ Richardson, TX 75083 \\ zdai@utdallas.edu \\ Edward Maydew \\ Kenan-Flagler Business School \\ University of North Carolina \\ Chapel Hill, NC 27599 \\ edward maydew@unc.edu
}

Douglas A. Shackelford

Kenan-Flagler Business School

University of North Carolina

Chapel Hill, NC 27599

and NBER

doug_shack@unc.edu

Harold H. Zhang

School of Management

University of Texas at Dallas

Richardson, TX 75083

harold.zhang@utdallas.edu 


\section{Capital Gains Taxes and Asset Prices: Capitalization or Lock-in?}

\section{Introduction}

This paper jointly tests two effects of capital gains taxation on equity trading: a demand-side capitalization effect and a supply-side lock-in effect. Previous studies have tested these effects separately, but, to our knowledge, this is the first study to evaluate them jointly and empirically document the relative dominance of each effect surrounding an event of a tax rate change. Employing an equilibrium approach, we show that in general their net tax effect on asset prices is ambiguous. Evaluating returns and trading volume around the 1997 reduction in the capital gains tax rate, we find evidence of the capitalization and the lock-in effects jointly affecting trading. In particular, the capitalization effect dominates the lock-in effect in the week following an increase in the probability of a reduction in the capital gains tax rate, as buyers respond to information that future capital gains tax rates will be lower. The lock-in effect, on the other hand, dominates the capitalization effect after the rate reduction actually became effective.

Taxation is one of the most prevalent market frictions in financial markets. It affects investors' decisions and distorts the valuation of assets. Capital gains taxes, in particular, play an important role in determining an investor's trading strategies and ultimately can affect asset prices. Because investors endogenously respond to the imposition of capital gains taxes, the tax effect on asset prices can be complicated and difficult to measure. In his review of taxes in the finance literature, Graham (2003) concludes that "Though intriguing in theory, the profession has made only modest progress in documenting whether investor taxes affect asset prices...we need more evidence about the importance of personal taxes affecting asset prices..." To date, research on the effects of investor level capital gains taxes on asset prices has produced conflicting results. Several studies report that the presence of capital gains tax reduces stock price and current stock return (see Guenther and Willenborg (1999), Lang and Shackelford (2000), Ayers, Lefanowicz, and Robinson, (2003), among others), while other studies document that imposing capital gains tax increases stock price and current stock return (see Feldstein, Slemrod, and Yitzhaki, (1980), Landsman and Shackelford (1995), Reese (1998), Poterba and Weisbenner (2001), Klein (2001), Blouin, Raedy, and 
Shackelford (2003), Jin (2006), Ellis, Li, and Robinson (2006), among others). The former is referred to as the capitalization effect of taxes and is often justified by the argument that investors would demand a lower price to buy the assets if they have to pay capital gains taxes in the future. The latter is referred to as the lock-in effect and is attributed to investors requiring higher prices to sell assets if they have to pay taxes on selling them. Recognizing that the two effects work in opposite directions, the purpose of this paper is to understand the interaction of the two effects and the circumstances under which one effect dominates the other surrounding a tax rate change.

Theoretical studies on taxes and asset pricing have been scarce and often focus on trading strategies for investors to avoid paying capital gains taxes and their impact on asset prices when investors face embedded capital gains on their asset holdings. For example, Constantinides (1983) shows that investors can rebalance their portfolios without triggering capital gains taxes if they are allowed to sell short assets in which they have embedded gains. This allows investors to separate their optimal liquidation of assets from their optimal consumption and investment policies. Klein (1999) introduces a general equilibrium model of asset pricing with capital gains taxes when investors face short sale constraints so that they cannot rebalance their portfolio without triggering capital gains taxes liability. He makes predictions about the effects of capital gains taxes on asset prices without explicitly solving for the equilibrium price. Viard (2000) analyzes the dynamic asset pricing effects and incidence of realization-based capital gains taxes. Under the assumption of small realization taxes, he derives the first-order conditions for equilibrium asset prices. To obtain the first-order effects, he linearizes the first-order conditions around the no-tax equilibrium. He finds that asset prices are increased by the current realization tax, to partly offset the sale disincentive associated with the tax, consistent with the lock-in effect. Shackelford and Verrecchia (2002) develop a trading model where the long-term and short-term capital gains tax rates differential creates a trade-off between optimal risk-sharing and optimal tax-related trading strategy. They show that sellers are reluctant to sell appreciated assets sooner because they are subject to higher capital gains taxes. To entice sellers, buyers must provide compensation in the form of higher sales prices. 
In this paper, we analyze the effects of capital gains taxation on prices, while jointly considering the capitalization effect and the lock-in effect. Intuitively, the capitalization argument approaches the tax effect from buyers' perspective (demand side), while the lock-in effect views the tax impact from sellers' perspective (supply side). A more complete analysis of capital gains tax effects must simultaneously allow for demand and supply to interact. In equilibrium, the net effect on stock markets of the capital gains tax will be the combination of both effects. Our study provides such a unified framework and offers predictions for the capital gains tax effect on security markets.

Our analysis suggests that a change in capital gains taxes influences asset prices by shifting both the demand for assets and the supply of assets. Specifically, when the capital gains tax is increased, the demand curve for assets is shifted down, reflecting the decline in prices required to attract buyers. An increase in the capital gains tax also shifts the supply curve up, reflecting the boost in prices required to entice current owners to sell. The equilibrium net tax effect on asset prices is ambiguous, depending on which effect dominates. An increase in capital gains taxes unambiguously reduces the float of assets (number of shares actively traded). In the event of a capital gains tax cut, the demand curve for the assets shifts up and the supply curve shifts down. The equilibrium net tax effect on asset price is still ambiguous, but the float of assets is unambiguously increased.

To detail the predictions of our analysis, suppose the capital gains tax rate is reduced. If the capitalization effect dominates the lock-in effect, stock prices will increase leading to higher current stock returns. Conversely, if the lock-in effect dominates the capitalization effect, we predict that stock prices will decrease and lower current stock returns. These effects are likely to apply to all stocks traded on the stock market and constitute the market wide capital gains tax effect on stock prices.

Furthermore, the capital gains tax effect will vary depending upon the characteristics of stocks because of their differences in tax costs. For instance, growth stocks (i.e., stock whose valuation depends largely on future dividend growth) are more likely to face capital gains taxes than income stocks (i.e., those stocks currently distributing dividends). Consequently, in the event of a capital gains tax cut, growth 
stocks should experience even higher returns than income stocks when the capitalization effect dominates the lock-in effect. For stocks with large price appreciation and a high percentage of tax sensitive investor ownership (such as individual investors and mutual funds), a capital gains tax cut will reduce investors' tax cost of selling these stocks for portfolio rebalancing when the lock-in effect will dominate, leading to even lower current returns on these stocks. These constitute the cross-sectional effect of a capital gains tax change on asset prices.

Although the capitalization effect and the lock-in effect co-exist, the relative importance of the two effects should vary around the timing of a capital gains tax rate change. Specifically, in the event of a capital gains tax cut, the capitalization effect (price increase caused by demand shift upward) will be stronger than the lock-in effect before the tax cut becomes effective and the lock-in effect (price decrease caused by supply shift downward) will dominate the capitalization effect after the tax rate cut effective date. The reason for the timing difference is that investors react to changes in the probability of a capital gains tax rate cut before the rates actually fall. In other words, buyers increase their demand for stocks in response to the news of future tax cut. Conversely, because capital gains are taxed upon realization, tax sensitive stockholders likely will refrain from selling shares with embedded gains until the capital gains tax rate cut becomes effective. Consequently, we select different event windows for a dominant capitalization effect and a dominant lock-in effect in our empirical investigation. Different event windows are critical for identifying the relative dominance of capitalization and lock-in. We perform the empirical tests of these predictions by examining return and volume responses to the 1997 capital gains tax cut on stocks included in the CRSP dataset for the periods between January 1, 1995 and December 31, 1997. Our empirical analysis confirms that while both the capitalization and the lock-in effects jointly influence asset prices, the magnitude of each effect differs across the timing of the tax cut and stocks with different characteristics.

The 1997 capital gains tax rate reduction provides a rare opportunity to jointly investigate the effects of capitalization and lock-in on asset prices. In late April, 1997, information leaked that the Democratic White House and the Republican Congressional leadership had reached an accord to reduce the capital gains tax rate. This news preceded 
the actual effective tax rate by about one week. During that interim week, we find that the capitalization effect dominated the lock-in effect. This is consistent with individuals, the only shareholders benefiting from reduced rates, buying shares (through both personal accounts and mutual funds) as the probability of lower capital gains tax rates when they sell in the future increased. Conversely, we find that the lock-in effect dominated the capitalization effect during the week following the effective date of the tax cut. This is consistent with the tax sensitive individual investors selling stocks (through both personal accounts and mutual funds) with large embedded gains after the tax cut became effective.

Although consistent with our prediction, broad market movements surrounding the effective date may reflect other factors moving the markets during those two weeks. Our cross-sectional analyses, however, do provide compelling evidence about the effects of capitalization and lock-in. Specifically, we find that:

- Non-dividend paying stocks experienced a stronger capitalization effect than dividend-paying stocks during the week the capitalization effect dominated.

- Stocks with large price appreciation in the past and high individual percentage ownership experienced stronger lock-in effect and earned lower immediate returns during the week the lock-in effect dominated.

- Trading volume was greater during the week immediately before and after the tax cut becomes effective

- Trading volume was greater for stocks with large embedded capital gains and a high percentage of individual and mutual fund ownership during the week the lock-in effect dominates.

Since constructing alternative explanations for these cross-sectional findings is difficult, we infer from these results that capitalization and lock-in effects jointly affect market returns in the predicted manner. 
The paper is organized as follows. Section 2 discusses the effect of capital gains taxes on stock prices and its empirical implications using a simple demand and supply framework. Section 3 lays out the empirical methodology and section 4 provides empirical analysis and discussions. Finally, section 5 concludes.

\section{Capital gains taxes and asset prices in an equilibrium framework}

Consider an economy in which tax sensitive investors are required to pay taxes on appreciation in stock value upon selling. The overall tax effect on stock prices will be affected by both stock buyers and sellers. In the presence of the capital gains taxes, stock buyers will require a lower price to acquire the stock to compensate them for their future tax liability (the capitalization effect); while stock sellers will require a higher price to sell the stock to recover their current tax cost (the lock-in effect). The former will shift the demand for the stock and the latter will move the supply for the stock at all price levels. To demonstrate the effect of capital gains tax on stock price, we use an equilibrium approach based on the demand and supply framework. We assume that the demand curve for the stock is downward-sloping so that investors are willing to buy more shares of the stock at lower prices and fewer shares at higher prices, and on the other hand, the supply curve is upward-sloping so that investors are willing to sell more shares at higher prices and fewer shares at lower prices, both before and after the capital gains taxes.

Figure 1 illustrates the effect of a capital gains tax change on stock price and the interaction between the two opposing forces: capitalization and lock-in. To facilitate the discussion in our empirical analysis, we examine the effect on stock price of a capital gains tax cut. At first, suppose that the initial capital gains tax rate is $\tau_{C}^{0}$. The demand and the supply for any particular stock are depicted as $D$ and $S$ in the graph and the intersection determines the equilibrium price $P_{0}$ and float of shares $Q_{0}$. Now, we introduce a capital gains tax cut from $\tau_{C}^{0}$ to $\tau_{C}^{1}$ and $\tau_{C}^{1}<\tau_{C}^{0}$. The demand curve shifts to the right from $D$ to $D$ ' due to increase in demand associated with the capitalization effect. At the same time the supply curve also shifts to the right from $S$ to $S$ ' due to increase in supply associated with the lock-in effect. In equilibrium, the new demand and supply 
curves intersect with each other at new equilibrium price $P_{1}$ and new float of shares $Q_{1}$. It is obvious that the new price could be higher or lower depending upon which effect dominates. However, the float of shares is clearly increased. In the event of a capital gains tax increase, the shift in demand and supply is reversed. Consequently, the float of shares is unambiguously decreased. However, the change in equilibrium price remains ambiguous depending on which effect dominates: the capitalization or the lock-in. In the appendix, we formalize the demand and supply analysis and analytically demonstrate the effect of capital gains taxes on stock price to be ambiguous depending upon the relative magnitude of the capitalization to that of the lock-in.

Our analysis above has the following empirical implications. First, when the capitalization effect dominates the lock-in effect, a reduction in the capital gains tax will cause an increase in the stock price (higher current stock returns). This will arise when buyers are more responsive to an imminent capital gains tax cut than are current sellers. Conversely, when the lock-in effect dominates the capitalization effect, a reduction in the capital gain tax rate will cause a decrease in the stock price (lower current stock returns). This will happen if current sellers are more responsive to the capital gains tax cut than are buyers. Second, the float of shares is inversely related to the capital gains taxes. When the capital gains tax is reduced, both the capitalization and the lock-in effects reinforce each other to increase the number of shares actively traded. The above implications apply to all stocks with embedded capital gains and thus represent market wide reactions to capital gains tax rate change.

Because of different effects of capital gains taxes on stock buyers and sellers, stocks with different characteristics will also be affected differently in the event of a capital gains tax change. Growth stocks are expected to offer larger future price appreciation than income stocks. A capital gains tax cut will reduce the buyer's future tax liability and attract more demand. These stocks will experience a greater price increase and higher returns than income stocks in the event of a capital gains tax cut. In general, dividend-paying stocks are more likely to be income stocks while non-dividend paying stocks are more likely to be growth stocks. This means that for the capitalization effect the stock returns are likely higher for non-dividend paying firms than dividend paying firms. From a stock seller's perspective, tax sensitive investors holding stocks with large 
long-term price appreciation will have lower current tax costs upon selling when the capital gains tax is reduced. Thus, tax sensitive investors will be more inclined to sell stocks with large embedded capital gains to rebalance their portfolio. This implies that in the event of a capital gains tax cut, stocks with large embedded capital gains will experience a larger price decline than will other stocks. These implications pertain to individual stock characteristics. We thus call them cross-sectional effects of a capital gains tax rate change.

In addition, investors anticipating the capital gains tax cut may withhold selling shares with embedded gains before the tax cut becomes effective (seller's strike). In this case, the supply curve may remain unchanged or even move up from $S$ to $S^{\prime \prime}$. The demand and supply curve may intersect at point $C$ or $D$. This will lead to a temporary increase in both the stock price and float of shares. This may provide an alternative explanation to a dominating capitalization effect before the capital gains tax cut becomes effective. In the next section, we empirically test both the market wide and crosssectional effects of a capital gains tax change by jointly considering the capitalization and the lock-in effects.

\section{Empirical Methodology}

To empirically test the above implications, we use the Taxpayer Relief Act of 1997 (TRA97) capital gains tax reduction as our event. The TRA97 lowered the top tax rate on capital gains from 28 percent to 20 percent for assets held more than 18 months. TRA97 is particularly attractive as an event because the tax cut was both large and relatively unexpected. Often tax legislation follows a protracted process with gradual changes in the probability of a particular bill becoming a law. In TRA97, however, Congress provided researchers with an attractive research setting by coming to rapid agreement on a large, unexpected reduction in capital gains tax rates.

Having a well-defined event is particularly important in this study because we need to define separate event windows for two opposing effects. The key to jointly identify the capitalization effect and the lock-in effect is to understand that stock buyers 
and sellers perceive the expected capital gains tax cut differently as we discussed above. ${ }^{1}$ They differ not only from required rate of return or valuation, but also from when they react to the news/event.

A buyer, in order to capture the expected tax cut benefit, will react to the capital gains tax cut information before the tax cut becomes effective. On the other hand, a seller who is subject to capital gains taxes will more likely sell shares with embedded capital gains to rebalance his portfolio after the tax cut becomes effective. As a result, the capitalization effect is more likely to dominate before the tax cut announcement and the lock-in effect is more likely to dominate after the tax cut becomes effective.

For the Taxpayer Relief Act of 1997 (TRA97), little information was released until Wednesday April 30, 1997, when the Congressional Budget Office (CBO) surprisingly announced that the estimate of 1997 deficit had been reduced by $\$ 45$ billion. Two days later on May 2, the President and Congressional leaders announced an agreement to balance the budget by 2002 and, among other things, reduce the capital gains tax rate. These announcements greatly increased the probability of a capital gains tax cut. $^{2}$ On Wednesday May 7, 1997, Senate Finance Chairman William Roth and House Ways and Means Chairman William Archer jointly announced that the effective date on any reduction in the capital gains tax rate would be May 7, 1997.

Given the above background, we choose Wednesday, April 30 to Tuesday, May 6, 1997 as the week that we expect the capitalization effect $\left(W K_{C}\right)$ to dominate as demand increases in reaction to the increased likelihood of a capital gains taxes cut. The same event window is used in Blouin, Hail, and Yetman (2005). Lang and Shackelford (2000) use a similar event window (April 29 to May 5, 1997). We then choose Wednesday May 7 to Tuesday May 13, 1997 as the week that we expect the lock-in effect $\left(W K_{L}\right)$ to

\footnotetext{
${ }^{1}$ If an investor has to rebalance his portfolio by adding positions in some stocks and reducing positions in other stocks around the capital gains tax cut period, he is more likely to add the positions when the tax rate cut announcement is imminent, and delay his selling until the tax rate cut is effective if he has embedded capital gains on the positions.

${ }^{2}$ There were some conflicting signals on the capital gains tax cut before April 1997 as detailed in Sinai and Gyourko (2004). Based on articles in the New York Times and Wall Street Journal they find that President Clinton had already said that "he might be willing to cut capital gains taxes to reach a budget compromise ..." in the first week of February, though at that point "the Administration's preference is for a capital gains tax increase." However, on February 13 and February 23 there were additional news reports suggesting that the White House would accept a tax cut. We view the surprising announcement by the CBO as the strongest indication for an imminent capital gains tax announcement.
} 
dominate as current shareholders sell their appreciated stocks to rebalance their portfolios.

Another important factor is that the capital gains rate reduction only applied to income that is reported on personal tax returns, i.e., capital gains from the selling of shares held directly by individuals or held indirectly by individuals in flow-through entities, such as mutual funds, partnerships, trusts, S corporations, or limited liability corporations that pass dividend income to investors' personal tax returns. Capital gains taxes are not levied on tax-deferred accounts (e.g., qualified retirement plans, including pensions, IRAs and 401(k)), tax-exempt organizations, and foreigners. Corporations pay capital gains taxes; however, the rate reduction in TRA97 did not apply to corporations. Thus, the ensuing tests predict variation in returns based on the amount of holdings by individual investors and mutual funds.

To capture the group of investors who are the most sensitive to the capital gains taxes, we construct proxies for the percentage of tax sensitive investor ownership of a stock (individual investors and/or mutual funds) using data on shares outstanding and shares owned by institutional investors. The data on the institutional investors' ownership are obtained from their quarterly filings with the U.S. Securities and Exchange Commission (known as Form 13F).

Let $R_{i t}$ be firm $i$ 's stock return at time $t$. To test the effect of a capital gains tax rate cut on stock prices, we formulate the basic empirical regression equations as follows: for firms with positive embedded gains

$$
\begin{aligned}
R_{i t}= & \alpha+\beta_{1} W K_{C}+\beta_{2} W_{L}+\beta_{3} W K_{C} * \text { Div }_{i(t-1)}+\beta_{4} W_{L} * \text { Gains }_{i(t-1)} * T_{S O} O_{i(t-1)} \\
& +\beta_{5} W_{C} * \text { Gains }_{i(t-1)} * \text { TSO }_{i(t-1)}+\beta_{6} \text { Beta_market }_{i}+\beta_{7} \text { Beta_momentum }_{i} \\
& +\gamma \text { Controls }+\varepsilon_{i t},
\end{aligned}
$$

$\underline{\text { for all firms }}$

$$
\begin{aligned}
R_{i t}= & \alpha+\beta_{1} W K_{C}+\beta_{2} W K_{L}+\beta_{3} W_{C} * \text { Div }_{i(t-1)}+\beta_{4} W K_{L} * \text { Gains }_{i(t-1)} *\left(1-L_{i(t-1)}\right) * T_{S O} O_{i(t-1)} \\
& +\beta_{5} W_{C} * \text { Gains }_{i(t-1)} * \text { TSO }_{i(t-1)}+\beta_{6} \text { Beta_market }_{i}+\beta_{7} \text { Beta_momentum }_{i} \\
& +\beta_{8} \text { WK }_{C} * \text { Gains }_{i(t-1)} * L_{i(t-1)} * T S O_{i(t-1)}+\beta_{9} \text { WK }_{L} * \text { Gains }_{i(t-1)} * L_{i(t-1)} * \text { TSO }_{i(t-1)} \\
& +\gamma \text { Controls } \varepsilon_{i t}
\end{aligned}
$$


where $W K_{C}$ represents the dummy variable for the week when we expect the capitalization effect to dominate (hereafter, we call $W K_{C}$ the capitalization week for brevity), $W K_{L}$ represents the dummy variable for the week when we expect the lock-in effect to dominate (hereafter we call $W K_{L}$ the lock-in week for brevity), $D i v_{i(t-1)}$ is the dummy variable which takes the value of 1 if there was no dividend distribution in the prior year and 0 otherwise, Gains $s_{i(t-1)}$ is the embedded capital gains prior to time $t$ and in our baseline case is measured as the past five year stock price appreciation, $T S O_{i(t-1)}$ is the percentage of shares of stock $i$ owned by tax sensitive investors at time $(t-1)$ and is measured either as the sum of individual investor and mutual fund ownership in the most recent past quarter or individual investor ownership alone, $L_{i(t-1)}$ is a dummy variable that takes the value of 1 if $\left(\right.$ Gains $\left._{i(t-1)}<0\right)$ and 0 otherwise, Beta_market ${ }_{i}$ is stock $i$ 's market return beta, Beta_momentum ${ }_{i}$ is stock $i$ 's beta on the momentum factor, and Controls refer to all other variables that may affect stock returns.

Our specifications above consider both the broad stock market reactions to the capital gains tax cut and the cross-sectional differences in the tax effect for different stocks with diverse characteristics. Intuitively, a capital gain tax cut will increase the demand for stock. Thus, in the event of a capital gains tax cut, the coefficient of the capitalization week dummy $\left(W K_{C}\right)$ will be positive $\left(\beta_{1}>0\right)$. Similarly, for existing tax sensitive shareholders contemplating selling shares with embedded capital gains, a tax cut will induce them to sell the stock to rebalance. When the lock-in effect dominates the capitalization effect, a tax rate cut will lead to lower returns on stocks with embedded capital gains resulting in a negative sign for the lock-in week dummy variable $\left(\beta_{2}<0\right)$. These constitute the broad market effect on stock prices of a capital gains tax cut.

Firms differ in their dividend policy and growth potential (and consequently their future capital gains tax liability) and the size of embedded capital gains and current tax costs upon selling. Thus, the magnitude of reaction to the capital gains tax cut will likely vary with the characteristics of these firms. Our analysis in the previous section suggests that in the event of a capital gains tax cut, the impact from demand side on stock return will be larger for growth stocks than for income stocks. This is captured by a positive 
interaction term $\left(W K_{C}{ }^{*} D i v_{i(t-1)}\right)$, indicating a larger price increase for growth stocks than income stocks during the capitalization week $\left(\beta_{3}>0\right)$.

On the other hand, for a current shareholder who faces a capital gains tax liability, a capital gains tax reduction offers a strong incentive for him to sell shares with large embedded capital gains to rebalance, consequently leading to large downward price pressure associated with the lock-in effect on the stock returns. Therefore during the week the lock-in effect dominates the capitalization effect, stocks with larger embedded capital gains and a higher percentage of tax sensitive investor ownership will experience lower stock returns. In our specifications above, this is captured by a negative $\left(\beta_{4}<0\right)$ interaction $\left(\right.$ WK $_{L} *$ Gains $\left._{i(t-1)} * T S O_{i(t-1)}\right)$ for firms with positive gains and interaction $\left(\right.$ WK $\left._{L} * \operatorname{Gains}_{i(t-1)} * T S O_{i(t-1)} *\left(1-L_{i(t-1)}\right)\right)$ for the specification on all firms.

As discussed in Section II, an alternative explanation to a dominating capitalization effect in the week before the capital gains tax cut is that tax sensitive investors may withhold selling stocks with large embedded gains, leading to a price runup. This is referred to as the "seller's strike." To empirically test if a price run-up in the week before the capital gains tax cut announcement is caused by a dominating capitalization effect or seller's strike, we include in our specifications the interaction $\left(W_{C}{ }^{*}\right.$ Gains $\left._{i(t-1)} * T S O_{i(t-1)}\right)$. If the seller's strike causes the price run-up, we would expect a positive coefficient for the interaction. Otherwise, the price increase is likely to be the result of a dominating capitalization effect.

In addition, we also include measures of systematic risk of individual stock returns to the market returns and the momentum factor in our regression analysis. This is motivated by the standard capital asset pricing theory and existing empirical evidence suggesting that systematic risks are important determinants of individual stock returns. Given that a tax cut is a market-wide event, the returns to the market portfolio and the momentum themselves will likely be affected by the event as well. Consequently, in our baseline specifications we include betas of the market returns and the momentum factor as control variables. We will discuss the results of using the beta adjusted stock returns as dependent variables in our robustness check later.

Our specification for all firms includes two additional interaction terms: $\left(\right.$ WK $\left._{C} * \operatorname{Gains}_{i(t-1)} * L_{i(t-1)} * T S O_{i(t-1)}\right)$ and $\left(\right.$ WK $\left._{L} * \operatorname{Gains}_{i(t-1)} * L_{i(t-1)} * T S O_{i(t-1)}\right)$. These interaction 
terms focus on the responses of loss firms to the capital gains tax cut in the capitalization week and the lock-in week. They allow us to further identify if tax sensitive investors will engage in tax efficient trading in the event of a capital gains tax change. Intuitively, tax sensitive investors should more aggressively sell stocks with large embedded capital losses before the capital gains tax is reduced to benefit from higher tax deduction. This would create some downward pressure on these stocks during the capitalization week. Consequently, the coefficient for $\left(W K_{C} * \operatorname{Gains}_{i(t-1)} * L_{i(t-1)} * T S O_{i(t-1)}\right)$ will be positive indicating that the prices of stocks with embedded losses are likely to decrease in the size of losses during the capitalization week because $\left(\right.$ Gains $\left._{i(t-1)}<0\right)$. On the other hand, since there is no lock-in on stocks with embedded losses and the capitalization effect remains during the lock-in week, the coefficient for $\left(W K_{C} * G a i n s_{i(t-1)} * L_{i(t-1)} * T S O_{i(t-1)}\right)$ will likely be negative indicating increased demand associated with the capitalization effect.

To test the prediction on the effect of the capital gains tax cut on the float of shares, we need to first provide a measure for the float of stock. Unlike the shares outstanding, the float of shares measures the number of shares actively traded and is usually less than shares outstanding. For example, shares owned by insiders sometimes are subject to certain restrictions and cannot be quickly sold in the market thus not included in the float; some long-term buy-and-hold investors are also less inclined to churn their portfolio for short-term price fluctuation. Their holdings are not included in the float during normal time.

However, for a major event, such as a capital gains tax cut, an investor may find it optimal to buy additional stocks and/or to sell some stocks with a large price appreciation to rebalance his portfolio. Trading from these investors is likely to temporarily increase trading volume. In particular, the increase in trading volume caused by the capital gains tax cut is likely to be concentrated in the few weeks when the tax cut is announced. We use trading volume as a proxy for the float of shares of stocks.

Let $v_{i t}$ be stock $i$ 's logarithmic weekly trading volume. Following Michaely and Vila (1996) and Dhaliwal and Li (2006), we first compute the excess trading volume as the difference between the weekly trading volume at time $t$ and the average weekly trading volume in the most recent past three months relative to the three month weekly average trading volume, i.e., 


$$
\Delta v_{i t}=\frac{v_{i t}-\frac{1}{13} \sum_{j=t-13}^{t-1} v_{i j}}{\frac{1}{13} \sum_{j=t-13}^{t-1} v_{i j}} .
$$

We then formulate our regression equations on the tax effect on the float of shares as follows:

for firms with positive embedded gains

$$
\begin{aligned}
\Delta v_{i t} & =\alpha+\beta_{1} W K_{C}+\beta_{2} W K_{L}+\beta_{3} W K_{C} * \text { Div }_{i(t-1)}+\beta_{4} W K_{L} * \text { Gains }_{i(t-1)} * T S O_{i(t-1)} \\
& +\beta_{5} W K_{C} * \text { Gains }_{i(t-1)} * T_{S O} O_{i(t-1)}+\gamma \text { Controls }+\varepsilon_{i t},
\end{aligned}
$$

for all firms

$$
\begin{aligned}
\Delta v_{i t} & =\alpha+\beta_{1} W K_{C}+\beta_{2} W K_{L}+\beta_{3} W K_{C} * \operatorname{Div}_{i(t-1)}+\beta_{4} W_{L} * \operatorname{Gains}_{i(t-1)} *\left(1-L_{i(t-1)}\right) * T_{S O} O_{i(t-1)} \\
& +\beta_{5} W_{C} * \operatorname{Gains}_{i(t-1)} * \text { TSO }_{i(t-1)}+\beta_{6} W K_{C} * \text { Gains }_{i(t-1)} * L_{i(t-1)} * T S O_{i(t-1)} \\
& +\beta_{7} W_{L} * \operatorname{Gains}_{i(t-1)} * L_{i(t-1)} * T S O_{i(t-1)}+\gamma \text { Controls }+\varepsilon_{i t}
\end{aligned}
$$

where the variables are defined the same as above and the controls are discussed in next section.

Our prediction for stock float suggests that the coefficients for $W K_{C}$ and $W K_{L}$ will be positive reflecting the market wide response in trading volume to a capital gains tax cut. The interaction term, $\left(W K_{C} * D i v_{i(t-1)}\right)$, will also be positive because more tax sensitive investors should buy shares of stocks with growth potentials during the week the capitalization effect dominates. Furthermore, the interaction term, $\left(W_{L} *\right.$ Gains $\left._{i(t-1)} * T S O_{i(t-1)}\right)$ will be positive because more tax sensitive investors should sell their holdings with large embedded capital gains to rebalance their portfolios during the week the lock-in effect dominates. In our discussions of the empirical analysis, we use trading volume to refer to the excess trading volume for brevity.

\section{Empirical analysis}

\section{A. Sample and Summary Statistics}

We use stocks included in the CRSP dataset between January 1, 1990 and December 31, 1997. Following Lang and Shackelford (2000) we focus on weekly returns. Explanatory variables include dividend dummy, embedded capital gains, the percentage 
of individual and/or mutual fund ownership of a stock, week dummies defined to identify the event period, measure of individual stock's exposure to the market return (Beta_market $i_{i}$, measure of individual stock's exposure to the momentum factor (Beta_momentum ${ }_{i}$ ), and various interaction terms to identify the tax effect.

We calculate the weekly return as follows

$$
R_{i t}=\sum \log \left(r_{i t}^{d}+1\right)
$$

where $r_{i t}^{d}$ is the daily return and $t$ runs from Wednesday to the following Tuesday to be consistent with the event windows. The logarithmic weekly volume is similarly calculated as

$$
v_{i t}=\sum \log \left(\operatorname{Vol}_{i t}^{d}\right)
$$

where $\operatorname{Vol}_{i t}^{d}$ is the daily trading volume of stock $i$ on day $t$ and the summation runs from Wednesday to the following Tuesday. We use both volumes in shares traded and in dollar amount for our empirical tests.

We obtain daily stock returns and trading volume from the daily CRSP data set. Dividend, stock price, and shares outstanding are extracted from the monthly CRSP data set. To obtain the percentage of shares of each stock owned by individual investors, we extract institutional investors' ownership as of March 31, 1997 from Form 13F submitted to the SEC by investment management companies. ${ }^{3}$ We then compute two measures of the tax sensitive ownership on stock $i$ at time $t\left(T_{S O} O_{i t}\right)$ as follows the percentage of individual investor ownership $\left(I N D_{i t}\right)$

$I N D_{i t}=1-$ Percentage of shares owned by institutional investors at time $t$ the percentage of individual investor and mutual fund ownership $\left(I N D \& M F_{i t}\right)$

$I N D \& M F_{i t}=I N D_{i t}+$ Percentage of shares owned by mutual funds at time $t$.

We exclude non-common shares such as preferred stocks from our analysis. Firms with missing observations are also removed. For our baseline case, we follow Klein $(1999,2001)$ and define the embedded capital gain as the price appreciation in the last five years. Specifically, the five year embedded capital gain is calculated as the price

\footnotetext{
${ }^{3}$ We thank Rabih Moussawi for providing the institutional stock ownership data. Ayers, Lefanowicz and Robinson (2003), Dhaliwal and Li (2006), and Dhaliwal, Krull, Li and Moser (2005), among many others, also use this measure to capture the extent to which individuals hold shares in the firm.
} 
appreciation in the past five years up to the most recent month prior to time $t$ for each stock. For instance, the five embedded gain for 3/31/1997 is calculated as a stock's price appreciation from February 1992 to February 1997. For robustness check, we also use embedded capital gains measured at two years and eight years and find that inferences largely hold.

To obtain measures of exposure of individual stock returns to the market return and the momentum factor, for each stock, we estimate a multiple regression of the firm's weekly excess return on the weekly market excess return and weekly momentum factor using data on these variables between $1 / 8 / 1992$ to $4 / 16 / 1997 .^{4}$ The regression slope for the market return and the momentum factor is used for Beta_market B $_{i}$ and Beta_momentum, , respectively.

For the empirical tests, we use weekly returns in the last three years $(1995,1996$ and 1997). Our control variables for the weekly return regressions include the dividend distribution dummy, the percentage of tax sensitive investor ownership, the embedded capital gains, the interaction terms $W K_{L} * G_{a i n s}(t-1), W K_{L} * T S O_{i(t-1)}, W K_{C} * G a_{i n s}(t-1)$, $W K_{C} * T S O_{i(t-1)}$, Gains $_{i(t-1)} * T S O_{i(t-1)}, T S O_{i(t-1)} * \operatorname{Div}_{i(t-1)}$, the size of the firm measured by the logarithm of firms' market capitalization at $t-1$, and the calendar effect represented by month and annual dummies. For the volume regressions, we use the dividend distribution dummy, the percentage of shares owned by individual investors and mutual funds, firm size, the interaction terms $\operatorname{Gains}_{i(t-1)} * T S O_{i(t-1)}, \operatorname{Gains}_{i(t-1)} * \operatorname{Div}_{i(t-1)}$, and the calendar effect as control variables.

Table 1 presents the basic summary statistics for variables used in our regression analysis for both the subsample of firms with positive embedded capital gains and the full sample including firms with embedded capital losses. Each variable is defined at the bottom of the table. The subsample consists of information on 2,565 firms with positive embedded gains for the past five years and a total of 266,252 observations. The average weekly return for firms with positive embedded capital gains is 0.31 percent with a standard deviation of 6.3 percent. In the meantime, the full sample including firms with

\footnotetext{
${ }^{4}$ To construct the weekly momentum factor, we use the daily data on the momentum factor (Up minus Down or UMD) obtained from Kenneth R. French's website. Six value-weighted portfolios formed on size and prior (2-12) returns are used to construct UMD. The portfolios formed monthly are the intersections of 2 portfolios formed on size and 3 portfolios formed on prior (2-12) return. UMD is the average return on the two high prior return portfolios minus the average return on the two low prior return portfolios.
} 
embedded capital losses consists of 412,730 firm-week observations and has a lower average weekly return of 0.29 percent and a slightly higher standard deviation of 6.83 percent. On average, about 48 percent of the firms in the gains subsample and 49 percent of all firms in the full sample did not pay dividends (recall that Div takes a value of one if the firm does not pay dividends). The average five-year price appreciation for the gains subsample is 210 percent with a standard deviation of 941 percent. The five year price appreciation is much lower at 123 percent with a standard deviation of 765 percent for the full sample. The five-year embedded capital gain is highly skewed with half of the firms gaining less than 79 percent for the gains subsample and about 27 percent for the full sample as indicated by the median. The average percentage of shares owned by individual investors is 68 percent with a standard deviation of 24 percent for the gains subsample. Individual and mutual funds together own 78 percent of stocks on average with a standard deviation of slightly less than 17 percent for the gains subsample. The mean and standard deviation for the individual and/or mutual fund ownership are of similar magnitude to those of the full sample. The average individual stock beta on the market return is 0.6 with a standard deviation of 0.53 for and the average beta on the momentum factor is much smaller at 0.02 with a relatively large standard deviation of 0.40 for the positive gains subsample. Similar mean and standard deviation are found for the full sample with all firms.

The trading volume for the gains subsample has a mean of 11.7 and a standard deviation of 2.2 when measured in logarithmic shares. The statistics are slightly higher at 14.4 for the mean and 2.7 for the standard deviation when measured in logarithmic dollar volume. The summary statistics for the trading volume for the full sample including both the gains and loss firms are of similar magnitude to those of the gains subsample. The excess trading volume has an average of 0.014 with a standard deviation of 0.72 for positive gains firms when measured in logarithmic shares and an average of 0.026 with a standard deviation of 0.75 when measured in logarithmic dollar volume. We also report the summary statistics for the adjusted weekly return after removing the systematic components associated with the market return and the momentum factor. The mean adjusted weekly return for individual stocks ranges from 0.05 to 0.07 percent with a 
standard deviation ranging between 6.1 to 6.7 percent for the two samples, respectively. The adjusted weekly return is much lower on average than the unadjusted return.

We use generalized least squares to estimate our regression model in order to account for correlated residuals in regressions. Specifically, we use clustered standard error estimates, which are shown to be unbiased in regression analysis using panel data sets by Peterson (2005). ${ }^{5}$

\section{B. Return Tests for Joint Tax Capitalization and Lock-in Effects}

Our first set of regression results is based on equation (1) and reported in Table 2. The first two columns of estimates and p-values are for the percentage of tax sensitive ownership (TSO) measured by individual investors and mutual funds combined, while the last two columns measure tax sensitive ownership using individual investors only. The coefficients for key variables are qualitative very similar. Consistent with our predictions, the coefficient estimate associated with $W K_{C}$ is positive and statistically significant at 1 percent. This indicates that the market reacted positively to the possibility of a capital gains tax cut. The weekly return for the capitalization week is 8.18 percent higher than the average weekly return when the tax sensitive ownership is measured by individual investors and mutual funds combined (IND\&MF), and is 6.04 percent higher when the tax sensitive ownership is measured by individual investors only (IND). The estimates are lower than the average return reported in Lang and Shackelford (2000) for the week between 4/29/1997 to 5/5/1997, but reasonable given that more controls are used in our regression. The estimate for $W K_{L}$ is negative and also statistically significant at 1 percent. The estimated coefficient suggests that the average weekly return in the lock-in week is about 2.0 percent (1.0 percent) lower than the average weekly return using IND\&MF $(I N D)$. This provides empirical support for a market wide dominating lock-in effect during the week immediately after the capital gains tax cut became effective.

Consistent with our predictions on the cross-sectional behavior of stock returns, the interaction term $\left(W K_{C} * D i v\right)$ is positive and highly statistically significant with a pvalue less than 1 percent. The estimated coefficient shows that non-dividend paying

\footnotetext{
${ }^{5}$ We use SAS PROC MIXED procedure to estimate our models treating firm as our subject so that each firm is one cluster. The goodness of fit for this procedure is given by the -2 residual log likelihood.
} 
stocks yield 1.7 percent higher returns on average during the capitalization week than do dividend-paying stocks for the same period for both measures of tax sensitive ownership. Lang and Shackelford (2000) report that non-dividend-paying firms experience 4.25 percent higher weekly return on average. The coefficient estimate associated with the interaction term $\left(W K_{L} * G a i n s * T S O\right)$ is negative at -0.34 percent based on IND\&MF and negative at -0.22 percent based on IND. Both are highly statistically significant with pvalues less than 1 percent. This suggests that stocks with large embedded capital gains and high individual investor ownership have lower returns during the lock-in week. The coefficient implies that for firms with the average percentage of individual and mutual fund ownership, a one standard deviation increase in five year embedded capital gains will yield 2.5 percent $(-0.34 \% \times 941 \% \times 77.8 \%)$ lower weekly returns during the lock-in week. For firms with an average five year embedded capital gains, a one standard deviation increase in the percentage of individual and mutual fund ownership leads to 12 basis points $(-0.34 \% \times 210 \% \times 16.8 \%)$ lower weekly returns during the lock-in week. When the tax sensitive ownership is measured by individual investors only, the corresponding reduction in the average weekly returns during the lock-in week is lower at 1.4 percent and 11 basis points, respectively.

The above findings are consistent with both investors buying stocks as the probability of a capital gains tax cut increases before the announcement and tax sensitive investors selling their shares after the effective date of capital gains tax cut. Investors respond by increasing their demand for stocks and driving up prices during the capitalization week. This is particularly evident for non-dividend paying growth stocks, whose returns are more likely to face capital gains taxation. After the lower tax rate became effective, individual investors sensitive to capital gains tax liabilities were more inclined to sell positions with large embedded capital gains to rebalance their portfolios. This leads to a lower price for stocks with large embedded capital gains and a higher percentage of individual stock ownership during the lock-in week.

Our findings suggest that a dominant lock-in effect is stronger in a subset of stocks that have both large embedded capital gains and high tax sensitive ownership in the week after the effective date of the tax cut. Given that TRA97 directly affects 
individual investors and mutual funds with large embedded capital gains, this finding is consistent with our prediction on the relation between stock price and capital gains taxes.

The coefficient for the interaction term $\left(\right.$ WK $_{C}{ }^{*}$ Gains $\left.* T S O\right)$ is positive but statistically insignificant for both measures of the tax sensitive ownership. The p-value for the coefficient estimate is above 90 percent for both the IND\&MF and IND. This suggests that there is no empirical support for the seller's strike, an alternative explanation of the price run-up during the capitalization week. The reason is, if investors were withdrawing from the market after the announcement of a rate cut but before the effective date, we would expect share prices to increase during the capitalization week for the appreciated shares that were going to be sold after the effective date. Since the coefficient on interaction term $\left(\mathrm{WK}_{C}{ }^{*}\right.$ Gains $\left.{ }^{*} T S O\right)$ is insignificant, we infer that increased demand largely accounted for the increase in prices during the capitalization week, rather than a seller's strike.

Our regression analysis also provides the following findings. Consistent with the capital asset pricing theory, a firm's exposure to systematic market risk has a positive effect on the firm's return. The estimated coefficient for Beta_market ranges from 0.11 to 0.12 percent and statistically significant at less than 1 percent level across the two regressions. Firms' exposure to the momentum factor also has a positive effect on returns. The coefficient for Beta_momentum ranges from 0.07 to 0.08 and significant at around 1.5 percent level for across the two regressions. Stocks with higher tax-sensitive investor ownership experience about 0.2 percent higher weekly returns on average. The interaction between $W K_{L}$ and the embedded capital gains is significantly positive. This may be caused by demand from institutional investors that did not face a capital gains tax cut.

Stocks with higher tax sensitive investor ownership experience a lower average weekly return during the capitalization week and a higher average weekly return during the lock-in week. Non-dividend paying stocks with higher tax sensitive investor ownership also yield a lower weekly return on average. Firm size has a negative and significant effect on stock returns.

Although not reported in the table, we find that the annual dummy is highly statistically significant for year 1995 but not for year 1996. The monthly dummies on the 
other hand are all statistically significant indicating the existence of monthly return variation. Given our panel data, firm characteristic variables (gains, dividend, size and individual and/or mutual fund ownership) also act as controls for the fixed effect in the test.

\section{Return Tests with all Firms}

For firms without embedded capital gains, the lock-in will not likely have a significant effect on stock returns. However, tax-sensitive investors with embedded capital losses may sell their holdings before the tax cut becomes effective so that they can benefit from the higher tax rebate under higher tax rate. ${ }^{6}$ If so, firms with embedded capital losses and high tax sensitive investor ownership will experience some downward price pressure during the week before the tax cut announcement. For these stocks, the price run-up caused by the capitalization effect, which increases the demand from investors who have no existing positions in them and investors who are not subject to taxation, will likely be attenuated.

On the other hand, because there is no lock-in effect on stocks with embedded capital losses after the tax cut announcement, the selling pressure will likely be small while the capitalization effect remains for these stocks. To check the robustness of our findings of joint capitalization and lock-in effects and to test the hypotheses on firms with embedded capital losses, we estimate equation (2) which incorporates two additional terms: $\left(W K_{C}{ }^{*}\right.$ Gains $\left.^{*} L^{*} T S O\right)$ and $\left(W K_{L}{ }^{*}\right.$ Gains $\left.* L * T S O\right)$ using observations on all firms.

Table 3 reports the regression results with the two additional interaction terms. Both the signs and magnitude of the effects of key variables are similar to those for firms with positive embedded capital gains only. Specifically, the coefficient for the capitalization week is 8.61 percent (6.42 percent) with a p-value less than 1 percent when the tax sensitive ownership is measured by percentage of shares owned by individual investors and mutual funds (individual investors only). The coefficient for the lock-in week is -1.46 percent and -0.76 percent for the two measures of tax sensitive

\footnotetext{
${ }^{6}$ Complex netting provisions, which are beyond the scope of this paper, govern the taxation of capital gains and losses (see Shackelford, 2000). That said, our predictions about the incentives to sell stocks with embedded capital losses before the rate fell assume that the investors can utilize the capital losses. More specifically, we assume a net capital gain position, i.e., total capital gains exceed total capital losses.
} 
ownership, respectively, and both are statistically significant at 2 percent level. Regarding the cross-sectional effect of the tax cut, we find that firms that do not distribute dividends earn 1.5 percent and 1.53 percent higher average weekly returns, during the week the capitalization effect dominates, for the two measures of tax sensitive ownership, respectively. This is slightly lower than the estimates using firms with positive embedded capital gains only. The coefficient estimate for the interaction $W K_{L} *$ Gains $^{*}(1-L) * T S O$ is negative at -0.29 percent and -0.17 percent for the two measures of tax sensitive ownership, respectively, and remains statistically significant at 3 percent level. The magnitude of the effect is again slightly lower than in the case with gains firms. Overall, the results for individual investors and mutual funds combined are stronger than for individual investors only, consistent with mutual funds taking into account tax costs in their investment decisions.

The coefficient for the interaction $W K_{C}{ }^{*} G a i n{ }^{*} T S O$ remains statistically insignificant with a high p-value (above 90 percent) for both measures of tax sensitive ownership. This suggests that stocks with embedded gains do not perform significantly different from stocks with embedded losses during the capitalization week. This shows that there is no strong evidence for "seller's strike" during the capitalization week. In other words, the run-up in prices during the capitalization week appears to be driven more by increased demand for shares, rather than a withdrawal from the market by sellers. The coefficient estimates for Beta_market and Beta_momentum remain positive and statistically significant. The magnitudes are lower than in the case with positive gains firms.

For the firms with embedded capital losses, the coefficient estimates are consistent with our predictions. Specifically, firms with embedded capital losses (where Gains will be less than zero and $L$ will take on a value of one) and high tax sensitive ownership earn lower weekly average returns than other firms during the week before the tax cut became effective. The effect is statistically significant at the conventional 5 percent test level ( $\mathrm{p}$-value is 2.9 percent for IND\&MF and 4.8 percent for IND only). Firms with embedded capital losses also earn higher average weekly returns during the week after the tax cut takes effect. For stocks with average individual investor and mutual fund ownership, a 10 percent increase in embedded capital losses leads to 18 basis points 
$(-2.35 \% \times 77.8 \% \times 10 \%)$ higher average weekly return during the week after the tax cut became effective.

\section{Robustness Tests}

In this section, we perform robustness checks on our findings documented above. We focus on alternative measures of embedded capital gains and an alternative measure of stock returns that adjusts for the market return risk and the momentum factor as in a conventional event study. Specifically, we re-estimate equation (2) measuring embedded capital gains as the price appreciation in the past two years and past eight years. We also re-estimate equations (1) and (2) using adjusted individual stock returns that remove the systematic components attributed to the market returns and the momentum factor. In all of our robustness tests, tax sensitive ownership is measured as the percentage of shares owned by individual investors and mutual funds.

Table 4 reports the results for two year and eight year embedded capital gains for all firms, respectively. The signs of the coefficient estimates for all key variables remain the same as for the baseline case with five year embedded capital gains. The coefficient estimates are also all statistically significant for the key variables except for the interaction $\left(W_{L} *\right.$ Gains $\left.^{*}(1-L) * T S O\right)$ for the two year embedded gains measure. This is attributed to the relatively small embedded gains for a relatively short holding period. Indeed, our calculation indicates that the average two year embedded capital gain is only 78 percent, which is substantially lower than the average five year embedded capital gain of 210 percent. There are 42 percent of firms with two year embedded losses compared to 35 percent of firms with losses when the embedded capital gains is calculated using the past five year price appreciation. Consequently, the lock-in effect is much weaker with a two year holding period than with a five or eight year holding period. The interaction $\left(\right.$ WK $_{C}{ }^{*}$ Gains $\left.* T S O\right)$ remains statistically insignificant for both two and eight year embedded gains measures, indicating no evidence for seller's strike at these holding periods either. On firms with embedded losses at two year holding period, the coefficient estimate for the lock-in week has the predicted sign and is statistically significant but the coefficient estimate is insignificant for the capitalization week. With an eight year holding period, the estimated coefficients for both the capitalization week and the lock-in 
week have the correct signs but are statistically insignificant at the conventional five percent level.

In Table 5 we report the regression results for both positive gains firms and all firms when the dependent variable is measured as the adjusted individual stock returns. To construct the adjusted individual stock returns, we subtract the systematic components (Beta_market*Market return) and (Beta_momentum*Momentum factor) from the raw individual stock returns. Again, the signs of the estimated coefficients for all key variables remain the same as for the baseline cases reported in Tables 1 and 2. The estimated coefficients for all key variables are also statistically significant except for the interaction $\left(W K_{C}{ }^{*} D i v\right)$. The other significant change is the magnitude of the coefficient estimate for $W K_{C}$. It is reduced from around 8 percent to about 2 percent. Both changes in the estimated coefficients for $W K_{C}$ and $\left(W K_{C}{ }^{*}\right.$ Div) can be attributed to the fact that the market return and the momentum factor themselves are also affected by the event of the tax cut. Indeed, our regression results discussed earlier consistently show that stock returns across the broad market are higher during the capitalization week. This implies that the market return itself is higher during the capitalization week. Therefore, given that individual firms have positive exposure to the market returns on average, when we remove the systematic component associated with the market returns we effectively reduce the price run-up in the adjusted returns. One could argue that because the market returns and the momentum factors are also affected by the capital gains tax cut event, to examine the overall effect on individual stock returns it is important not to remove the systematic components associated with these factors. From that perspective, Tables 2 and 3 show the complete effects of a capital gains tax cut on stock returns.

\section{E. Trading Volume Tests for Joint Tax Capitalization and Lock-in Effects}

Next, we test the impact of the tax cut on trading volume. Table 6 shows the results of the regression analysis for firms with positive embedded gains only and all firms using both trading volume in shares and in dollar amount. Consistent with our predictions, both the capitalization week and the lock-in week exhibit higher trading volume both in logarithmic shares and logarithmic dollar amount. The effect is highly statistically significant with p-value less than 1 percent. The estimated coefficient for the 
capitalization week is consistently above 2 percent. Specifically, when the trading volume is measured by logarithmic shares, the excess volume is about 2.5 percent higher for both the positive gains subsample and the full sample than average trading volume for the capitalization week. The excess trading volume is about 2 percent higher than average trading volume for the capitalization week when measured by logarithmic dollar amount. The estimated coefficient for $W K_{L}$ suggests that the trading volume is about 0.55 percent higher for the lock-in week than the average trading volume when measured by logarithmic shares. The increase in trading volume is slightly smaller at about 0.4 percent on the logarithmic dollar amount. The finding holds for both the positive gains subsample and the full sample.

The coefficient estimate for the interaction term $W K_{C} *$ Div is statistically insignificant at the 5 percent p-value level. Consistent with our prediction on the crosssectional effect of a capital gains tax cut on trading volume, the estimated coefficient for the interaction term $W K_{L} *$ Gains $*(1-L) * T S O$ is positive and highly statistically significant at p-value less than 1 percent. Stocks with large embedded capital gains and high tax sensitive investor (individual investor and mutual fund) ownership experience higher trading volume during the lock-in week. Specifically, for the positive gains subsample, a one standard deviation increase in five year embedded capital gains leads to 0.63 percent $(0.086 \times 941 \% \times 77.8 \%)$ higher trading volume on the logarithmic shares during the lock-in week for firms with average percentage of individual investor and mutual fund ownership. For firms with the average five-year embedded capital gains, a one standard deviation increase in the percentage of individual investor and mutual fund ownership increases the trading volume by 0.03 percent $(0.086 \times 210 \% \times 16.8 \%)$ on the logarithmic shares during the lock-in week. For the full sample consisting of all firms, the increase in the trading volume in logarithmic shares is 0.53 and 0.018 percent, respectively. The results are similar when the trading volume is measured in logarithmic dollar amount. For instance, for a one standard deviation increase in the five year embedded gains, the trading volume increase by 0.48 percent for the positive gains subsample and 0.39 percent for the full sample for firms with average individual investor and mutual fund ownership. Our findings are consistent with investors selling shares of 
stocks with large accumulated capital gains to rebalance their portfolio after the lower capital gains tax takes effect.

The interaction term $\left(W K_{C}{ }^{*}\right.$ Gains $\left.* T S O\right)$ has an insignificant effect on the trading volume for both the positive gains subsample and the all firm full sample. This is consistent with our finding on the return tests of the seller's strike. As in the return tests, we incorporate two additional interaction terms: $\left(W K_{C}{ }^{*}\right.$ Gains $\left.{ }^{*} L^{*} T S O\right)$ and $\left(W K_{L}{ }^{*}\right.$ Gains $\left.{ }^{*} L^{*} T S O\right)$ in the regression with all firms. As we discussed in the return tests with loss firms, investors may sell shares with embedded capital losses before the tax cut to benefit from higher tax rebate under higher tax rate. Therefore, the coefficient for ( $W K_{C}{ }^{*}$ Gains ${ }^{*}{ }^{*} T S O$ ) will likely be negative because the Gains is less than zero for loss firms. After the tax cut becomes effective, because there is no lock-in effect on firms with embedded capital losses, the capitalization effect is likely to increase the demand and the coefficient for $\left(W K_{L} *\right.$ Gains $\left.* L * T S O\right)$ will also likely be negative. While the estimated coefficients for the two additional interactions terms have the correct sign in three out of four cases, they are not statistically significant at conventional test level. While not reported in the table, other control variables have little effect on the excess trading volume. Annual and monthly dummies are all statistically significant as in the return tests.

Our findings on the effect on the trading volume of a capital gains tax cut are consistent with the results reported in Blouin, Raedy, and Shackelford (2003). Using announcements of quarterly earnings and additions to the Standard and Poors 500 index as their events, they document that trading volume falls with the incremental taxes saved by deferring the sale of appreciated asset values. In our case, as the capital gains tax is reduced, the incremental taxes saved will decrease. This will lead to an increase in trading volume. In other words, in their case holding period incentive causes current shareholders to restrain from selling shares, which shifts supply to the left. In our setting, current shareholders sell some stocks with embedded gains to rebalance their portfolios, leading to the supply curve shifted to the right. 


\section{Conclusions}

We analyze the effect of capital gains taxes on returns and trading volume using an equilibrium approach that incorporates both the capitalization effect and the lock-in effect. Extant studies separately test the capitalization effect and the lock-in effect. To our knowledge, this is the first to jointly model and test both effects. Our analysis predicts that in the presence of capital gains taxes, the net effect on asset prices is ambiguous. If the capitalization effect dominates (is dominated by) the lock-in effect, the stock price decrease (increase). The relative strength of the capitalization effect and the lock-in effect depends on the time period surrounding a tax rate change and firm characteristics, such as dividend policy, growth potential, and the percentage of tax sensitive individual ownership. The number of shares actively traded increases (decreases) as the capital gains tax rate decreases (increases).

We empirically test our predictions using weekly returns and trading volume from January 1, 1995 to December 31, 1997, focusing on the 1997 capital gains tax rate cut. Consistent with our predictions, we find evidence of both the capitalization and the lockin effect. In particular, the capitalization effect dominates the lock-in effect the week between news of the rate reduction and the effective date of the rate cut, (4/30/1997$5 / 6 / 1997)$, reflecting anticipation of the proposed tax cut making it into law. Weekly stock returns are on average higher by about 8 percent than average weekly returns during the capitalization week. Moreover, non-dividend paying stocks have higher stock returns during the capitalization week (about 1.6 percent) than dividend paying stocks.

In contrast, the lock-in effect dominates the capitalization effect during the first week after the rate reduction becomes effective (5/7/1997-5/13/1997). The weekly stock returns are on average 1 to 2 percent lower during the lock-in week. Stocks with large embedded capital gains and high percentage of individual investor and mutual fund ownership experience lower returns on average during the lock-in week. A one standard deviation increase in the five year embedded capital gains leads to 2.5 percent lower weekly returns during the lock-in week for firms with average percentage of individual investor and mutual fund ownership.

Stocks experience higher trading volume during the week immediately before and after the tax cut becomes effective. Stocks with large embedded capital gains for the past 
five years and high individual ownership also show higher trading volume, consistent with increased supply for these stocks. The results are robust for both measures of volume in shares and in dollar amount. All these findings are consistent with our model predictions.

This paper joins an emerging literature in financial economics (see Reese [1998], Guenther and Willenborg [1999], Poterba and Weisbenner [2001], and Klein [2001], among others) in providing evidence that personal capital gains taxes affect equity trading. Together, these papers challenge a common assumption in financial economics that shareholder taxes are irrelevant in pricing stocks. Although the inferences that can be drawn from these papers are limited to the settings that they examine, their findings call for additional research to examine whether equity prices vary as shareholder taxes change and with the mix of taxable and non-taxable shareholders. 


\section{References}

Ayers, B., Lefanowicz C., Robinson, J., 2003, Shareholder taxes in acquisition premiums: The effect of capital gains taxation, Journal of Finance 58, 2785-2803.

Blouin, J., L. Hail, and M. Yetman, 2005, Capital gains taxes, pricing spreads and arbitrage: Evidence from cross-listed firms in the U.S., working paper, The Wharton School and University of California at Davis.

Blouin, J., J. Raedy, and D. Shackelford, 2003, Capital gains taxes and equity trading: Empirical Evidence, Journal of Accounting Research 41, 611-651.

Constantinides, G., 1983, Capital market equilibrium with personal tax, Econometrica 51, 611-636.

Constantinides, G., 1984, Optimal stock trading with personal taxes: Implications for prices and abnormal January returns, Journal of Financial Economics 13, 65-89.

Dhaliwal, D., L. Krull, O. Li, and W. Moser, 2005, Dividend taxes and implied cost of equity capital, Journal of Accounting Research 43:675-708.

Dhaliwal, D. and O. Li, 2006, Investor tax heterogeneity and ex-dividend day trading volume, Journal of Finance 61, 463-490.

Ellis, K., O. Li, and J. Robinson, 2006, Capital gains taxes and IPO under-pricing, working paper, University of California, Davis, University of Notre Dame, and University of Texas at Austin.

Feldstein, M., J. Slemrod, and S. Yitzhaki, 1980, The effects of taxation on the selling of corporate stock and the realization of capital gains, Quarterly Journal of Economics 94, 777-791.

Graham, J., 2003, Taxes and Corporate Finance: A Review, Review of Financial Studies $16,1075-1129$.

Guenther, D., and M. Willenborg, 1999, Capital gains tax rates and the cost of capital for small business: Evidence from the IPO market, Journal of Financial Economics 53, 385408.

Klein, P., 1999, The capital gain lock-in effect and equilibrium returns, Journal of Public Economics 71, 355-378.

Klein, P., 2001, The capital gain lock-in effect and long horizon return reversal, Journal of Financial Economics 59, 33-62. 
Landsman, W., and D. Shackelford, 1995, The lock-in effect of capital gains taxes: Evidence from the RJR Nabisco leverage buyout, National Tax Journal 48, 245-259

Lang, M., and D. Shackelford, 2000, Capitalization of capital gains taxes: Evidence from stock price reactions to the 1997 rate reduction, Journal of Public Economics 76, 69-85.

Jin, L., 2006, Capital gain tax overhang and price pressure, Journal of Finance 61, 13991431.

Michaely, R. and J. Vila, 1996, Trading volume with private valuation: Evidence from the ex-dividend day, Review of Financial Studies 9, 471-509.

Peterson, M., 2005, Estimating standard error in finance panel data sets: Comparing approaches, working paper, Kellogg School of Management, Northwestern University.

Poterba, J., and S. Weisbenner, 2001, Capital gains tax rules, tax-loss trading, and turnof-the-year returns, Journal of Finance 56, 353 - 368.

Reese, W., 1998, Capital gains taxation and stock market activity: Evidence from IPOs, Journal of Finance 53, 1799-1820.

Shackelford, D., 2000, Stock market reaction to the capital gains tax changes: Empirical evidence from the 1997 and 1998 Tax Acts, in Tax policy and the Economy 14, edited by James M. Poterba, National Bureau of Economics Research and MIT Press (Cambridge, MA.), 67-92.

Shackelford, D. and R. Verrecchia, 2002, Intertemporal tax discontinuities, Journal of Accounting Research 40:1, 205-222.

Sinai, T. and J. Gyourko, 2004, The asset price incidence of capital gains taxes: Evidence from the Taxpayer Relief Act of 1997 and publicly-traded real estate firms, Journal of Public Economics 88, 1543-1560.

Viard, A., 2000, Dynamic asset pricing effects and incidence of realization-based capital gains taxes, Journal of Monetary Economics 46, 465-488. 


\section{Appendix: A simple model of the effect on stock price of capital gains tax}

Investors in the economy trade multiple stocks indexed by $i$. To facilitate our exposition, we introduce the following notations. Let $P_{i t}$ be the time $t$ market price of stock $i, D_{i t}$ be the dividend distributed in period $t$ on stock $i, B_{i t}$ be the time $t$ tax basis of the investor who currently owns stock $i, \tau_{g}$ be the capital gains tax rate, and $\tau_{d}$ be the dividend tax rate. We denote $P_{i t}^{D}$ as the price willing to pay for a share of stock $i$ by buyers at time $t$ and $P_{i t}^{S}$ as the price willing to accept for a share of stock $i$ by sellers at time $t$. Thus, $P_{i t}^{D}$ and $P_{i t}^{S}$ represent the demand and supply curves at time $t$, respectively.

As in Section II, We assume that the demand curve for the stock is downward sloping while the supply curve for the stock is upward sloping. Furthermore, we assume that investors' demand for the stock is determined by the expected payoff of investing in the stock and the supply is determined by investors' reservation value of the stock and the immediate tax cost upon selling.

The demand curve for the stock can then be represented as follows:

$$
P_{i t}^{D}=E_{t}\left[\frac{P_{i t+1}+D_{i t+1}\left(1-\tau_{d}\right)-G_{i t+1} \tau_{g}}{1+r_{i}}\right]
$$

where $r_{i}$ is the discount rate applied to the cash flow of stock $i$ and $G_{i t+1}$ represents the investors' anticipated capital gain realization. We assume that the anticipated capital gain realization takes the following form:

$$
G_{i t+1}=\alpha_{i}\left(P_{i t+1}-P_{i t}\right) \text {, }
$$

where $\alpha_{i} \in(0,1]$. This specification takes into account that investors who purchase the shares have to pay the market price, which serves as the basis for computing buyers' capital gains taxes when they sell in the following period. ${ }^{7}$ Moreover, parameter $\alpha_{i}$ is used to allow investors to use tax efficient trading strategies to reduce their realized capital gains. $^{8}$

\footnotetext{
${ }^{7}$ This will be the case if the investor uses the last-in and first-out (LIFO) rule in calculating his tax liability.

${ }^{8}$ This also allows sellers to have tax basis different from the current price.
} 
On the other hand, to characterize the supply curve, we assume that sellers' reservation value of the stock (excluding the tax cost) is a fraction of current market price of the stock to simplify the derivation. Specifically, a typical tax sensitive shareholder with embedded capital gains, who contemplates selling, will require a price high enough to compensate him for his reservation value and tax liability. This implies:

$$
P_{i t}^{S}=\rho_{i} P_{i t}+\left(P_{i t}-B_{i t}\right) \tau_{g}
$$

where $\rho_{i} P_{i t}$ represents the seller's net-of-tax reservation value for a share of stock $i$ and $\left(P_{i t}-B_{i t}\right) \tau_{g}$ is the seller's capital gains tax. We assume that the seller's net-of-tax reservation value is less than the market price $\left(0<\rho_{i} \leq 1\right)$ because the tax burden is borne by both sellers and buyers in equilibrium. ${ }^{9}$

In equilibrium, the demand for the company shares equals the supply of the shares, and the price paid by the buyer equals the price received by the seller (including taxes), i.e.,

$$
P_{i t}^{D}=P_{i t}^{S}
$$

Substituting (A2) into (A1) and using the market clearing condition (A4), we arrive at the following equilibrium price for stock $i$ in the presence of taxes

$$
P_{i t}=E_{t}\left[\frac{P_{i t+1}\left(1-\alpha_{i} \tau_{g}\right)+D_{i t+1}\left(1-\tau_{d}\right)+\left(1+r_{i}\right) \tau_{g} B_{i t}}{\left(1+r_{i}\right)\left(\rho_{i}+\tau_{g}\right)-\alpha_{i} \tau_{g}}\right] .
$$

Rewriting equation (A5) recursively, we obtain the price of stock $i$ at time $t$ as follows:

$$
P_{i t}=E_{t}\left[\sum_{j=t+1}^{\infty}\left(\frac{1-\alpha_{i} \tau_{g}}{\left(1+r_{i}\right)\left(\rho_{i}+\tau_{g}\right)-\alpha_{i} \tau_{g}}\right)^{j-1} \frac{D_{i j}\left(1-\tau_{d}\right)+\left(1+r_{i}\right) \tau_{g} B_{i j-1}}{\left(1+r_{i}\right)\left(\rho_{i}+\tau_{g}\right)-\alpha_{i} \tau_{g}}\right] .
$$

Assuming that the dividend $D_{i j}$ grows at a constant rate $d_{i}$ and the tax basis $B_{i j}$ grows at rate $b_{i}$, we have the following simplified expression for the price of stock $i$ at time $t$ :

\footnotetext{
$9 \rho_{i}=1$ only when the capital gains tax rate is zero.
} 


$$
P_{i t}=\frac{D_{i t+1}\left(1-\tau_{d}\right)}{\left[\left(1+r_{i}\right) \rho_{i}-d_{i}\right]+\left(1+r_{i}-\alpha_{i}+\alpha_{i} d_{i}\right) \tau_{g}}+\frac{\left(1+r_{i}\right) \tau_{g} B_{i t}}{\left[\left(1+r_{i}\right) \rho_{i}-b_{i}\right]+\left(1+r_{i}-\alpha_{i}+\alpha_{i} b_{i}\right) \tau_{g}} .
$$

Denote the first term in equation (A7) as " $\mathrm{X}_{i}$ " and the second term as " $\mathrm{Y}_{i}$ ". Taking the first derivative of " $X_{i}$ " and " $Y_{i}$ " with respect to $\tau_{g}$, respectively, yields:

$$
\begin{gathered}
\frac{\partial X_{i}}{\partial \tau_{g}}=-\frac{\left(1+r_{i}-\alpha_{i}+\alpha_{i} d_{i}\right)}{\left[\left(1+r_{i}\right) \rho_{i}-d_{i}+\left(1+r_{i}-\alpha_{i}+\alpha_{i} d_{i}\right) \tau_{g}\right]^{2}} D_{i t+1}\left(1-\tau_{d}\right), \\
\frac{\partial Y_{i}}{\partial \tau_{g}}=\frac{\left(1+r_{i}\right) \rho_{i}-b_{i}}{\left[\left(1+r_{i}\right) \rho_{i}-b_{i}+\left(1+r_{i}-\alpha_{i}+\alpha_{i} b_{i}\right) \tau_{g}\right]^{2}}\left(1+r_{i}\right) B_{i t} .
\end{gathered}
$$

Equation (A8) is unambiguously negative and we call this capitalization effect of the capital gains tax because the term $X$ includes dividend and dividend growth which concern a potential buyer. Furthermore, the cross derivative of $\frac{\partial X_{i}}{\partial \tau_{g}}$ with respect to dividend growth $d_{i}, \frac{\partial^{2} X_{i}}{\partial \tau_{g} \partial d_{i}}$, is also negative. Hence, the magnitude of the capitalization effect becomes larger as the dividend growth rate of a company $\left(d_{i}\right)$ increases and the dividend tax rate $\left(\tau_{d}\right)$ decreases. This implies that in the event of a tax cut growth stocks will experience larger price increase than income stocks.

The sign of Equation (A9) depends upon the size of the investors' embedded capital gains over time. We have a positive lock-in effect if the following condition holds:

$$
\frac{\left(1+r_{i}\right) \rho_{i}}{b_{i}}>1
$$

The above inequality suggests that the lock-in effect depends positively on stock $i$ 's discount (or capitalization) rate and the investor's net-of-tax reservation price but is inversely related to the rate at which investors' tax basis grows. If we interpret the capitalization rate as the average appreciation rate of the stock price, then the left-handside measures the size of embedded capital gains. If the appreciation rate is high and the investor demands a high reservation price relative to the tax basis growth rate, the embedded capital gains are large and inequality (A10) will be satisfied. In this case, there 
is a positive lock-in effect. On the other hand, if the appreciation rate is low and the investors demand a very low reservation price relative to the tax basis growth rate, the investors will have little embedded capital gain or even a capital loss and there will be no lock-in effect. To empirically identify a dominant lock-in effect, we need to focus on stocks with large embedded capital gains for tax sensitive investors.

The combined effect of capital gains tax on stock price is given by

$$
\frac{\partial P_{i t}}{\partial \tau_{g}}=\frac{\partial X_{i}}{\partial \tau_{g}}+\frac{\partial Y_{i}}{\partial \tau_{g}} .
$$

Overall, because the capitalization effect $\left(\partial X_{i} / \partial \tau_{g}<0\right)$ and the lock-in effect $\left(\partial Y_{i} / \partial \tau_{g}>0\right)$ work in opposite direction, the net effect of capital gains tax on stock price is ambiguous. If the capitalization effect dominates, the net effect of capital gains tax on stock price will be negative; if the lock-in effect dominates, the net effect of capital gains tax is positive. 
Table 1: Summary Statistics

\begin{tabular}{lrrrrr}
\hline \multicolumn{1}{c}{ Variables } & Mean & Median & Std. Dev. & \multicolumn{1}{c}{ Min } & Max \\
\hline \multicolumn{5}{c}{ Panel A: firms with positive embedded gains } \\
\multicolumn{7}{c}{} & & & & \\
\hline Wret_raw (\%) & 0.3104 & 0.0000 & 6.2960 & -181.44 & 135.73 \\
Vol & 11.6678 & 11.7448 & 2.1799 & 4.6051 & 19.1538 \\
\$vol & 14.3994 & 14.3232 & 2.6909 & 3.8474 & 23.7085 \\
Size & 12.2155 & 11.9715 & 2.0472 & 6.9157 & 19.0198 \\
Div & 0.4811 & 0.0000 & 0.4996 & 0.0000 & 1.0000 \\
Gains(5-year) & 2.1045 & 0.7902 & 9.4135 & 0.0009 & 1041.00 \\
IND & 0.6833 & 0.7232 & 0.2356 & 0.0000 & 0.9999 \\
IND\&MF & 0.7784 & 0.8091 & 0.1682 & 0.0904 & 1.0000 \\
Beta_market & 0.6025 & 0.5635 & 0.5345 & -1.4465 & 2.6963 \\
Beta_momentum & 0.0196 & 0.0274 & 0.4026 & -3.1574 & 1.5292 \\
Adjret(\%) & 0.0728 & -0.0177 & 6.1407 & -180.61 & 134.72 \\
AdjVol & 0.0140 & -0.0013 & 0.7222 & -5.7668 & 5.3690 \\
Adj\$Vol & 0.0341 & 0.0138 & 0.7513 & -5.6760 & 6.2128 \\
\hline
\end{tabular}

Panel B: all firms

\begin{tabular}{lrrrrr}
\hline Wret_raw(\%) & 0.2894 & 0.0000 & 6.8263 & -188.87 & 179.17 \\
Vol & 11.7174 & 11.7875 & 2.1648 & 4.6051 & 19.1538 \\
\$vol & 14.2302 & 14.1294 & 2.7316 & 2.2380 & 23.7085 \\
Size & 12.0967 & 11.8605 & 2.1190 & 5.2587 & 19.3035 \\
Div & 0.4931 & 0.0000 & 0.4999 & 0.0000 & 1.0000 \\
Gains(5-year) & 1.2322 & 0.2727 & 7.6477 & -0.9834 & 1041.00 \\
IND & 0.6887 & 0.7258 & 0.2294 & 0.0000 & 0.9999 \\
IND\&MF & 0.7804 & 0.8110 & 0.1657 & 0.0904 & 1.0000 \\
Beta_market & 0.6039 & 0.5597 & 0.5410 & -1.4986 & 2.6963 \\
Beta_momentum & 0.0146 & 0.0235 & 0.4050 & -3.1574 & 1.5292 \\
Adjret(\%) & 0.0476 & -0.0401 & 6.7033 & -189.01 & 179.43 \\
AdjVol & 0.0140 & -0.0043 & 0.7231 & -5.7668 & 5.3690 \\
Adj\$Vol & 0.0258 & 0.0024 & 0.7514 & -5.6760 & 6.2128 \\
\hline
\end{tabular}

Wret is the weekly stock return calculated as $R_{i t}^{w}=\sum \log \left(r_{i t}^{d}+1\right)$ and $r_{i t}^{d}$ is the daily return and $t$ runs from Wednesday to the following Tuesday; $\mathrm{Vol}$ is the sum of daily logarithmic volume running from Wednesday to the following Tuesday; Size is the logarithm of the market value in prior month; $\$$ Vol is the sum of daily logarithmic dollar volume running from Wednesday to the following Tuesday; Div is a dummy variable that takes a value of 1 if the company did not pay any dividend in the prior year, zero otherwise; Gains measures the 5-year holding gains as of prior month; and IND is the percentage of individual ownership, calculated as one minus the percentage of shares held by institution investors as of the prior quarter; IND\&MF is the percentage of shares owned by individual investors and mutual funds in prior quarter; Beta_market and Beta_momentum are the beta estimates of regressing weekly individual stock returns on the market return and the momentum factor; and Adjret is the adjusted weekly return after removing the systematic components associated with the market return and the momentum factor. Adj Vol (Adj \$Vol) is computed difference between the current weekly volume and the average weekly volume in shares (dollar amount) in the past three months relative to the three month weekly average volume (equation (3)). 
Table 2: Return Tests for Tax Capitalization and Lock-In---positive gains firms

\begin{tabular}{|c|c|c|c|c|c|}
\hline \multirow[t]{2}{*}{ Variables } & \multirow{2}{*}{$\begin{array}{c}\text { Predicted } \\
\text { signs }\end{array}$} & \multicolumn{2}{|c|}{ Individuals and Mutual Funds } & \multicolumn{2}{|c|}{ Individuals only } \\
\hline & & Estimate & $p$-value & Estimate & $p$-value \\
\hline$W K_{C}$ & + & 8.180 & $(0.0001)$ & 6.044 & $(0.0001)$ \\
\hline$W K_{L}$ & - & -1.999 & $(0.0044)$ & -1.003 & $(0.0111)$ \\
\hline$W K_{C} * D i v$ & + & 1.684 & $(0.0001)$ & 1.685 & $(0.0001)$ \\
\hline$W K_{L} *$ Gains $* T S O$ & - & -0.339 & $(0.0001)$ & -0.217 & $(0.0036)$ \\
\hline$W K_{C}{ }^{*}$ Gains $* T S O$ & & 0.016 & $(0.9055)$ & -0.004 & $(0.9691)$ \\
\hline Beta_market & + & 0.113 & $(0.0002)$ & 0.119 & $(0.0002)$ \\
\hline Beta_momentum & & 0.082 & $(0.0145)$ & 0.073 & $(0.0140)$ \\
\hline Div & & 0.066 & $(0.5458)$ & -0.135 & $(0.0553)$ \\
\hline TSO & & 0.223 & $(0.0095)$ & 0.211 & $(0.0012)$ \\
\hline Gains & & 0.006 & $(0.0302)$ & 0.004 & $(0.0178)$ \\
\hline$W K_{L} *$ Gains & & 0.274 & $(0.0001)$ & 0.147 & $(0.0075)$ \\
\hline$W K_{L} * T S O$ & & 2.446 & (0.0099) & 1.363 & $(0.0299)$ \\
\hline Gains*TSO & & -0.013 & $(0.0397)$ & -0.012 & $(0.0287)$ \\
\hline$W K_{C} * T S O$ & & -7.537 & $(0.0001)$ & -5.541 & $(0.0001)$ \\
\hline$T S O * D i v$ & & -0.536 & $(0.0001)$ & -0.323 & $(0.0008)$ \\
\hline$W K_{C}{ }^{*}$ Gains & & -0.018 & $(0.8149)$ & -0.008 & $(0.8823)$ \\
\hline Size & & -0.030 & $(0.0003)$ & -0.026 & $(0.0013)$ \\
\hline Sample size & & 266 & & 266 & \\
\hline -2 residual log likelihood & & -720 & & -720 & \\
\hline
\end{tabular}

The dependent variable is Wret the weekly stock return calculated as $R_{i t}^{w}=\sum \log \left(r_{i t}^{d}+1\right)$ and $r_{i t}^{d}$ is the daily return and $t$ runs from Wednesday to the following Tuesday. $W K_{C}$ is the week from 4/30/1997 to 5/6/1997; $W K_{L}$ is the week from 5/7/1997 to 5/13/1997; Div is a dummy variable that takes value of 1 if the company did not pay any dividend in the prior year, zero otherwise; Gains measures the 5-year holding gains as of the prior month; and TSO is the tax sensitive investor ownership measured either by the percentage of shares owned by individual investors and mutual funds $(I N D \& M F)$ in the prior quarter or individual investors alone (IND); and Beta_market and Beta_momentum are the beta estimates of regressing weekly individual stock returns on the market return and the momentum factor.

All the estimates are in percentages; year dummies and month dummies are included in all specifications to control for possible calendar effects; model (1) uses the percentage of shares owned by both individual investors and mutual funds as the measure of tax sensitive ownership; and model (2) uses individual investors only as the measure of the tax sensitive ownership. 
Table 3: Return Tests for Tax Capitalization and Lock-In---for all firms

\begin{tabular}{|c|c|c|c|c|c|}
\hline \multirow[t]{2}{*}{ Variables } & \multirow{2}{*}{$\begin{array}{c}\text { Predicted } \\
\text { signs }\end{array}$} & \multicolumn{2}{|c|}{ Individuals and Mutual Funds } & \multicolumn{2}{|c|}{ Individuals only } \\
\hline & & Estimate & p-value & Estimate & p-value \\
\hline$W K_{C}$ & + & 8.614 & $(0.0001)$ & 6.420 & $(0.0001)$ \\
\hline$W K_{L}$ & - & -1.464 & $(0.0100)$ & -0.755 & $(0.0223)$ \\
\hline$W K_{C} * D i v$ & + & 1.498 & $(0.0001)$ & 1.525 & $(0.0001)$ \\
\hline$W K_{L} *$ Gains $^{*}(1-L) * T S O$ & - & -0.285 & $(0.0004)$ & -0.174 & $(0.0308)$ \\
\hline$W K_{C}{ }^{*}$ Gains $* T S O$ & & 0.013 & $(0.9222)$ & -0.005 & $(0.9670)$ \\
\hline$W K_{C} *$ Gains $* L * T S O$ & + & 2.302 & $(0.0291)$ & 2.338 & $(0.0477)$ \\
\hline$W K_{L} *$ Gains $* L * T S O$ & - & -2.352 & $(0.0059)$ & -2.335 & $(0.0134)$ \\
\hline Beta_market & + & 0.073 & $(0.0079)$ & 0.074 & $(0.0074)$ \\
\hline Beta_momentum & & 0.072 & $(0.0259)$ & 0.072 & $(0.0257)$ \\
\hline Div & & 0.040 & $(0.6712)$ & -0.161 & $(0.0094)$ \\
\hline TSO & & 0.106 & $(0.1461)$ & 0.090 & $(0.1036)$ \\
\hline Gains & & 0.004 & $(0.1090)$ & 0.003 & $(0.0385)$ \\
\hline$W K_{L} *$ Gains & & 0.241 & $(0.0001)$ & 0.128 & $(0.0226)$ \\
\hline$W K_{L} * T S O$ & & 1.607 & $(0.0388)$ & 0.833 & $(0.1213)$ \\
\hline Gains*TSO & & -0.009 & $(0.1592)$ & -0.008 & $(0.0969)$ \\
\hline$W K_{C} * T S O$ & & -7.687 & $(0.0001)$ & -5.671 & $(0.0001)$ \\
\hline$T S O * D i v$ & & -0.469 & $(0.0001)$ & -0.246 & $(0.0040)$ \\
\hline$W K_{C}{ }^{*}$ Gains & & -0.019 & $(0.8109)$ & -0.009 & $(0.8586)$ \\
\hline Size & & -0.025 & $(0.0005)$ & -0.023 & $(0.0013)$ \\
\hline Sample size & & 412 & & 412 & \\
\hline -2 residual log likelihood & & $-1,05$ & & $-1,05$ & \\
\hline
\end{tabular}

The dependent variable is Wret the weekly stock return calculated as $R_{i t}^{w}=\sum \log \left(r_{i t}^{d}+1\right)$ and $r_{i t}^{d}$ is the daily return and $t$ runs from Wednesday to the following Tuesday. $W K_{C}$ is the week from 4/30/1997 to 5/6/1997; $W K_{L}$ is the week from 5/7/1997 to 5/13/1997; Div is a dummy variable that takes value of 1 if the company did not pay any dividend in the prior year, zero otherwise; Gains measures the 5-year holding gains as of the prior month; and TSO is the tax sensitive investor ownership measured either by the percentage of shares owned by individual investors and mutual funds (IND\&MF) in the prior quarter or individual investors alone (IND); $L$ is a dummy variable that takes value of 1 if the embedded gain (Gains) is less or equal to 0 and takes value of 0 otherwise; and Beta_market and Beta_momentum are the beta estimates of regressing weekly individual stock returns on the market return and the momentum factor.

All the estimates are in percentage; year dummies and month dummies are included in all specifications to control for possible calendar effects; model (1) uses the percentage of shares owned by both individual investors and mutual funds as the measure of tax sensitive ownership; and model (2) uses individual investors only as the measure of the tax sensitive ownership. 
Table 4: Robustness check---for all firms with different holding periods

\begin{tabular}{|c|c|c|c|c|c|}
\hline \multirow[t]{2}{*}{ Variables } & \multirow{2}{*}{$\begin{array}{c}\text { Predicted } \\
\text { signs }\end{array}$} & \multicolumn{2}{|c|}{ Holding period $=2$ yrs. } & \multicolumn{2}{|c|}{ Holding period $=8$ yrs. } \\
\hline & & Estimate & $p$-value & Estimate & $p$-value \\
\hline$W K_{C}$ & + & 8.712 & $(0.0001)$ & 8.538 & $(0.0001)$ \\
\hline$W K_{L}$ & - & -1.606 & $(0.0088)$ & -1.945 & $(0.0016)$ \\
\hline$W K_{C} * D i v$ & + & 1.029 & $(0.0003)$ & 0.917 & $(0.0038)$ \\
\hline$W K_{L} *$ Gains $^{*}(1-L) * T S O$ & - & -1.408 & $(0.1069)$ & -0.344 & $(0.0140)$ \\
\hline$W K_{C}{ }^{*}$ Gains $^{*} T S O$ & & -0.450 & $(0.7167)$ & -0.047 & $(0.7880)$ \\
\hline$W K_{C}{ }^{*}$ Gains $^{*}{ }^{*} * T S O$ & + & -1.805 & $(0.2839)$ & 2.081 & $(0.0672)$ \\
\hline$W K_{L} *$ Gains $^{*} L^{*} T S O$ & - & -3.905 & $(0.0176)$ & -1.465 & $(0.1297)$ \\
\hline Beta_market & + & 0.072 & $(0.0090)$ & 0.112 & $(0.0002)$ \\
\hline Beta_momentum & & 0.068 & $(0.0347)$ & 0.062 & $(0.0635)$ \\
\hline Div & & 0.058 & $(0.5442)$ & -0.020 & $(0.8455)$ \\
\hline TSO & & 0.089 & $(0.2281)$ & 0.153 & $(0.0460)$ \\
\hline Gains & & -0.058 & $(0.2580)$ & 0.001 & $(0.3756)$ \\
\hline$W K_{L} *$ Gains & & 1.307 & $(0.0918)$ & 0.310 & $(0.0134)$ \\
\hline$W K_{L} * T S O$ & & 1.753 & $(0.0294)$ & 2.423 & $(0.0040)$ \\
\hline Gains*TSO & & 0.052 & $(0.3755)$ & -0.006 & $(0.1757)$ \\
\hline$W K_{C} * T S O$ & & -8.344 & $(0.0001)$ & -7.648 & $(0.0001)$ \\
\hline TSO *Div & & -0.485 & $(0.0001)$ & -0.350 & $(0.0061)$ \\
\hline$W K_{C}{ }^{*}$ Gains & & 0.829 & $(0.4650)$ & 0.106 & $(0.4589)$ \\
\hline Size & & -0.026 & $(0.0004)$ & -0.022 & $(0.0021)$ \\
\hline Sample size & & 415 & & 339 & \\
\hline -2 residual log likelihood & & $-1,05$ & & -903 & \\
\hline
\end{tabular}

The dependent variable is Wret the weekly stock return calculated as $R_{i t}^{w}=\sum \log \left(r_{i t}^{d}+1\right)$ and $r_{i t}^{d}$ is the daily return and $t$ runs from Wednesday to the following Tuesday. $W K_{C}$ is the week from 4/30/1997 to 5/6/1997; $W K_{L}$ is the week from 5/7/1997 to 5/13/1997; Div is a dummy variable that takes value of 1 if the company did not pay any dividend in the prior year, zero otherwise; Gains measures the 5-year holding gains as of the prior month; and TSO is the tax sensitive investor ownership measured by the percentage of shares owned by individual investors and mutual funds $(I N D \& M F)$ in the prior quarter; $L$ is a dummy variable that takes value of 1 if the embedded gain (Gains) is less or equal to 0 and takes value of 0 otherwise; and Beta_market and Beta_momentum are the beta estimates of regressing weekly individual stock returns on the market return and the momentum factor.

All the estimates are in percentage; year dummies and month dummies are included in all specifications to control for possible calendar effects; model (1) uses the embedded capital gains calculated based on the past two year price appreciation for the prior month; and model (2) uses the embedded capital gains calculated based on the past eight year price appreciation for the prior month. 
Table 5: Robustness check---with market and momentum adjusted returns

\begin{tabular}{|c|c|c|c|c|c|}
\hline \multirow[t]{2}{*}{ Variables } & \multirow{2}{*}{$\begin{array}{c}\text { Predicted } \\
\text { signs }\end{array}$} & \multicolumn{2}{|c|}{ Positive gains firms } & \multicolumn{2}{|c|}{ All firms } \\
\hline & & Estimate & $p$-value & Estimate & $p$-value \\
\hline$W K_{C}$ & + & 2.266 & $(0.0019)$ & 2.343 & $(0.0003)$ \\
\hline$W K_{L}$ & - & -2.181 & $(0.0018)$ & -1.755 & $(0.0019)$ \\
\hline$W K_{C} * D i v$ & + & 0.469 & $(0.1671)$ & 0.336 & $(0.2180)$ \\
\hline$W K_{L} *$ Gains $^{*}(1-L) * T S O$ & - & -0.339 & $(0.0001)$ & -0.294 & $(0.0001)$ \\
\hline$W K_{C}{ }^{*}$ Gains $* T S O$ & & -0.004 & $(0.9708)$ & -0.037 & $(0.7191)$ \\
\hline$W_{C} *$ Gains $* L * T S O$ & + & & & 3.221 & $(0.0026)$ \\
\hline$W_{L} *$ Gains $* L * T S O$ & - & & & -2.109 & $(0.0133)$ \\
\hline Div & & 0.021 & $(0.8486)$ & -0.028 & $(0.7824)$ \\
\hline TSO & & 0.382 & $(0.0001)$ & 0.301 & $(0.0002)$ \\
\hline Gains & & 0.005 & $(0.0374)$ & 0.004 & $(0.1409)$ \\
\hline$W K_{L} *$ Gains & & 0.277 & $(0.0001)$ & 0.250 & $(0.0001)$ \\
\hline$W K_{L} * T S O$ & & 2.678 & $(0.0045)$ & 1.989 & $(0.0101)$ \\
\hline Gains*TSO & & -0.012 & $(0.0505)$ & -0.007 & $(0.2281)$ \\
\hline$W K_{C} * T S O$ & & -2.467 & $(0.0131)$ & -2.136 & $(0.0146)$ \\
\hline$T S O *$ Div & & -0.592 & $(0.0001)$ & -0.527 & $(0.0001)$ \\
\hline$W K_{C}{ }^{*}$ Gains & & 0.010 & $(0.8559)$ & 0.027 & $(0.6370)$ \\
\hline Size & & -0.051 & $(0.0001)$ & -0.050 & $(0.0001)$ \\
\hline Sample size & & 266 & & 412 & \\
\hline -2 residual log likelihood & & -733 & & $-1,06$ & \\
\hline
\end{tabular}

The dependent variable is Adjret the weekly stock return after removing the systematic components associated with the market return and the momentum factor from the weekly individual stock return where $R_{i t}^{w}=\sum \log \left(r_{i t}^{d}+1\right), r_{i t}^{d}$ is the daily return and $t$ runs from Wednesday to the following Tuesday. $W K_{C}$ is the week from 4/30/1997 to $5 / 6 / 1997$; $W K_{L}$ is the week from 5/7/1997 to 5/13/1997; Div is a dummy variable that takes a value of 1 if the company did not pay any dividend in the prior year, zero otherwise; Gains measures the 5-year holding gains as of the prior month; and TSO is the tax sensitive investor ownership measured by the percentage of shares owned by individual investors and mutual funds $(I N D \& M F)$ in the prior quarter; $L$ is a dummy variable that takes value of 1 if the embedded gains (Gains) is less or equal to 0 and takes value of 0 otherwise.

All the estimates are in percentage; year dummies and month dummies are included in all specifications to control for possible calendar effect; model (1) uses firms with positive five year embedded capital gains only; and model (2) uses all firms. 
Table 6: Volume Tests for Tax Capitalization and Lock-In

\begin{tabular}{|c|c|c|c|c|c|}
\hline \multirow[t]{2}{*}{ Variables } & \multirow[t]{2}{*}{$\begin{array}{c}\text { Predicted } \\
\text { signs }\end{array}$} & $\begin{array}{l}\text { Volume } \\
\text { (1) }\end{array}$ & $\begin{array}{c}\text { \$volume } \\
\text { (2) }\end{array}$ & $\begin{array}{l}\text { Volume } \\
\text { (1) }\end{array}$ & $\begin{array}{l}\text { \$volume } \\
\text { (2) }\end{array}$ \\
\hline & & \multicolumn{2}{|c|}{ Positive gains firms } & \multicolumn{2}{|c|}{ All firms } \\
\hline \multirow[t]{2}{*}{$W K_{C}$} & + & 2.454 & 2.024 & 2.495 & 2.108 \\
\hline & & $(0.0001)$ & $(0.0001)$ & $(0.0001)$ & $(0.0001)$ \\
\hline \multirow[t]{2}{*}{$W K_{L}$} & + & 0.549 & 0.403 & 0.558 & 0.439 \\
\hline & & $(0.0015)$ & $(0.0046)$ & $(0.0002)$ & $(0.0004)$ \\
\hline \multirow[t]{2}{*}{$W K_{C} *$ Div } & + & -0.546 & -0.494 & -0.389 & -0.329 \\
\hline & & $(0.0864)$ & $(0.0615)$ & $(0.1773)$ & $(0.1715)$ \\
\hline \multirow[t]{2}{*}{$W K_{L} *$ Gains $^{*}(1-L) * T S O$} & + & 0.086 & 0.066 & 0.088 & 0.065 \\
\hline & & $(0.0051)$ & $(0.0051)$ & $(0.0043)$ & $(0.0055)$ \\
\hline \multirow[t]{2}{*}{$W_{C}{ }^{*}$ Gains $* T S O$} & & 0.008 & 0.002 & 0.0003 & -0.007 \\
\hline & & $(0.7192)$ & $(0.8895)$ & $(0.9883)$ & $(0.6440)$ \\
\hline \multirow[t]{2}{*}{$W K_{C} *$ Gains $^{*}{ }^{*} * T S O$} & & & & -0.752 & -0.469 \\
\hline & & & & $(0.5363)$ & $(0.6481)$ \\
\hline \multirow[t]{2}{*}{$W K_{L} *$ Gains $^{*} L * T S O$} & & & & -0.025 & 0.443 \\
\hline & & & & $(0.9673)$ & $(0.4557)$ \\
\hline \multirow[t]{2}{*}{$W K_{C}{ }^{*}$ Gains $* L * D i v$} & & & & 1.515 & 1.333 \\
\hline & & & & $(0.2176)$ & $(0.2019)$ \\
\hline \multirow[t]{2}{*}{ Size } & & -0.012 & -0.023 & -0.044 & -0.033 \\
\hline & & $(0.1706)$ & $(0.0060)$ & $(0.0001)$ & $(0.0001)$ \\
\hline \multicolumn{2}{|l|}{ Sample size } & \multicolumn{2}{|c|}{226,923} & \multicolumn{2}{|c|}{352,672} \\
\hline \multicolumn{2}{|l|}{-2 residual log likelihood } & $-617,566$ & $-698,031$ & $-960,094$ & $-1,071,277$ \\
\hline
\end{tabular}

The dependent variable is the percentage excess trading volume either measured in logarithmic shares (1) or logarithmic dollar volume (2); $W K_{C}$ is the week from $4 / 30 / 1997$ to $5 / 6 / 1997 ; W K_{L}$ is the week from 5/7/1997 to 5/13/1997; Div is a dummy variable that takes a value of 1 if the company did not pay any dividend in the prior year, zero otherwise; Gains measures the 5-year holding gains as of the prior month; and TSO is the tax sensitive investor ownership measured by the percentage of shares owned by individual investors and mutual funds (IND\&MF) in the prior quarter; and $L$ is a dummy variable that takes value of 1 if the embedded gain (Gains) is less or equal to 0 and takes a value of 0 otherwise.

All estimates are in percentages; p-values are in parentheses; year and month dummies are included in all specifications. 


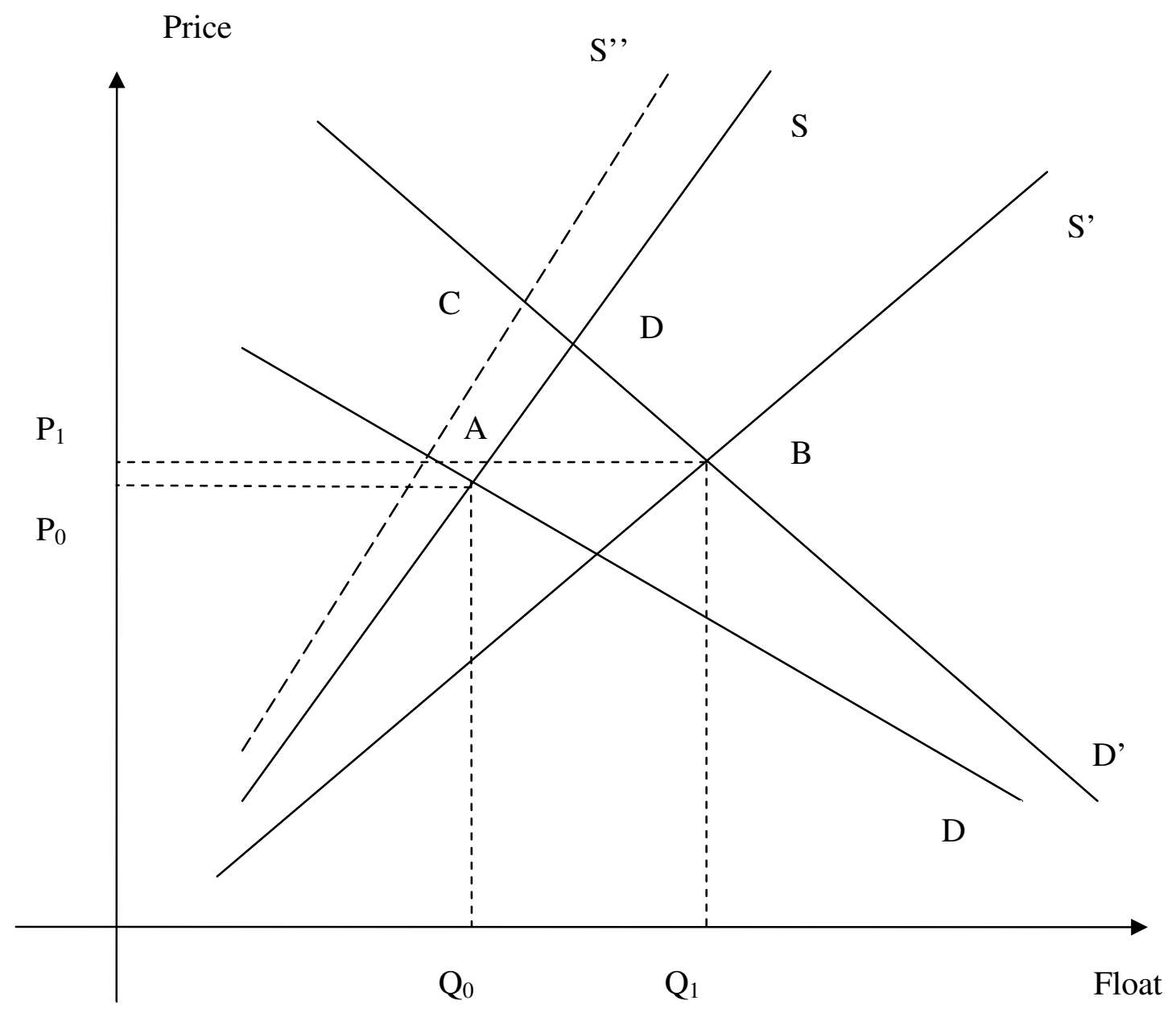

Figure 1: Effects of capital gains taxes on asset price and share float. $\left(\mathrm{P}_{0}, \mathrm{Q}_{0}\right)$ is the equilibrium price and quantity for the capital gains tax rate $\tau_{C}^{0}$ and $\left(\mathrm{P}_{1}, \mathrm{Q}_{1}\right)$ is the equilibrium price and quantity for the capital gains tax rate $\tau_{C}^{1}$. 